\title{
The P3 kimberlite, Wajrakarur Kimberlite Field, India: Mineralogy, and major and trace element compositions of olivines as records of their magmatic versus xenocrystic origin
}

\author{
Azhar M. Shaikh ${ }^{1}$, *, S. C. Patel ${ }^{1}$, E.V.S.S.K. Babu ${ }^{2}$, S. Ravi ${ }^{3}$ \\ ${ }^{1}$ Department of Earth Sciences, I.I.T. Bombay, Mumbai 400076, India, \\ azher.shaikh115@gmail.com, scpatel@iitb.ac.in \\ ${ }^{2}$ National Geophysical Research Institute, Uppal Road, Hyderabad 500007, India, evsskbabu@gmail.com \\ ${ }^{3}$ Geological Survey of India, Bandlaguda, Hyderabad 500068, India, sraviiyers@gmail.com
}

\section{Introduction}

We report the mineralogy and high precision microprobe trace element data of olivine from the Mesoproterozoic, diamondiferous P3 kimberlite in the Wajrakarur Kimberlite Field (WKF), southern India. Olivine macrocrysts in the kimberlite exhibit a core-rim structure which offers an opportunity to examine the variation in their minor and trace element $(\mathrm{Ni}, \mathrm{Ca}, \mathrm{Al}, \mathrm{Ti}, \mathrm{Mn}, \mathrm{Cr}$ and $\mathrm{Na}$ ) contents in order to differentiate melt-derived olivines from mantle olivines and also to distinguish multiple populations of mantle olivines.

\section{Petrography}

P3 kimberlite is inequigranular textured with macro- and microcrysts of olivine and phlogopite set in a groundmass dominated by phlogopite and monticellite with subordinate amounts of spinel, perovskite, ilmenite, apatite, serpentine, and calcite and rare baddeleyite. The groundmass is mostly uniform textured with occasional segregations. The rock additionally contains discrete xenocrysts of Cr-pyrope, diopside, and ilmenite; and highly altered microxenoliths. The microxenoliths contain relicts of Cr-diopside within a secondary mass of andradite \pm titanite \pm ferropargasite \pm kumtyubeite $\left(\mathrm{Ca}_{7}\left(\mathrm{SiO}_{4}\right)_{3} \mathrm{~F}_{2}\right) \pm$ zircon. The occurrence of kumtyubeite (F-analogue of humite) in microxenolith is reported for the first time from an Indian kimberlite.

\section{Mineral chemistry}

Although compositional zoning in olivine is masked by serpentinization, some olivine macrocrysts preserve a core-rim structure, where the rims represent chemically distinct overgrowths resulting from heterogeneous crystallization onto pre-existing cores. Two macrocryst core populations (olivine I and II) and one rim population (olivine III) are distinguished based on forsterite content and trace element concentrations. Olivine I cores are marked by higher Fo (90-93), Ni (2344-2816 ppm), and Cr (148$595 \mathrm{ppm}$ ) relative to olivine II cores (Fo 84-87, Ni 1601-2235 ppm, and Cr 107-261 ppm). Ca concentration is $162-610 \mathrm{ppm}$ in olivine I cores and $262-599 \mathrm{ppm}$ in olivine II cores. Olivine III rims which mantle either olivine I or II cores have intermediate Fo (88-89) and exhibit oscillatory zoning with variations in $\mathrm{Ca}$ (306-532 ppm), Ni (1132-2387 ppm), and $\mathrm{Cr}$ (175-397 ppm). The rims also exhibit elevated Ti contents (117-179 ppm) compared to olivine I and II cores (35-146 ppm).

Phlogopites of three distinct populations are recognised based on texture and composition: (i) phlogopite I occurs as macrocrysts and in nodules, and is marked by high $\mathrm{Cr}$, low $\mathrm{Ti}$ and $\mathrm{Ba}$ contents, (ii) phlogopite II forms phenocrysts, microphenocrysts, and overgrowth rims on phlogopite I macrocrysts, and has high $\mathrm{Cr}$ and $\mathrm{Ti}$, and moderate Ba contents; and (iii) phlogopite III forms a late generation of phenocrysts, microphenocrysts, and scattered groundmass needles and contains low $\mathrm{Ti}$ and $\mathrm{Cr}$ and high $\mathrm{Ba}$ and $\mathrm{F}$. Spinel grains exhibit atoll structure and are zoned from cores of $\mathrm{Cr}-\mathrm{Fe}-\mathrm{Al}-$ $\mathrm{Mg}$ spinel to rims of $\mathrm{Mg}-\mathrm{Ti}$ magnetite. Groundmass ilmenites are rich in $\mathrm{Cr}$ and $\mathrm{Mg}$ compared to xenocrystic ilmenites. Two generations of apatite are present, the first generation being richer in $\mathrm{F}$ and poorer in $\mathrm{Sr}$ than the second generation.

Unlike the nearby P2-west, P5, P12 and P13 intrusions in the WKF which show the lamproitic affinity, P3 intrusion shows mineral characteristics such as phlogopite-kinoshitalite- 
eastonite trend of mica, compositional trend- 1 of groundmass spinels, and the presence of groundmass monticellite which are typical of worldwide archetypal kimberlites. The intrusion is classified as a phlogopite-monticellite kimberlite.

\section{Discussion}

Origin of olivine core and rim

The absence of any groundmass mineral inclusions, the presence of deformation and resorption features in olivine I and II cores are indicative of their mantle origin. This is supported by their wide range of Fo and high Ni contents relative to olivine III rims. The high Fo and Ni contents of olivine I cores are similar to those of olivine in xenoliths of garnet lherzolite and garnet harzburgite reported from P3 and P4 intrusions (Nehru and Reddy, 1989) (Fig. 1a). Therefore, olivine I cores are interpreted to be inherited from such mantle xenoliths. In contrast, the relatively Fe-rich composition of olivine II cores falls outside the field of xenocrystic olivines from most of the worldwide kimberlites. Some workers have attributed the origin of such Fe-rich olivines to a proto-kimberlite melt, whereas others have linked it to some megacryst suites. The Fo and Ni contents of olivine II cores in P3 overlap with those of olivine megacrysts from P4 lamproite in the WKF (authors' unpublished data), and Monastery and Jagersfontein kimberlites in South Africa (Gurney et al., 1979; Hops et al., 1992) (Fig.1a). Equilibration temperatures calculated for olivine I and II cores using the Al-in olivine thermometer of De Hoog et al. (2010), intersect the xenolith geotherm beneath the WKF at assumed pressures of 40-60 kbar and the P-T stability field of mantle xenoliths from the WKF. This indicates that the olivine cores are not related to a proto-kimberlite melt because otherwise, their equilibration temperatures would have been higher than that indicated by xenolith geotherm at any given depth. Similar Fe-rich olivine cores are known from two lamproite intrusions in the WKF: TK1 (Shaikh et al., 2016) and P4 (authors' unpublished data), whose parental melt compositions are likely to have been different from that of P3 kimberlite. The occurrence of Fe-rich olivines of similar composition in two contrasting magma types (kimberlite and lamproite) indicates that Fe-rich olivines are not related to a proto-kimberlite or proto-lamproite melt, but are derived from a megacryst suite produced by a distinct metasomatic event.
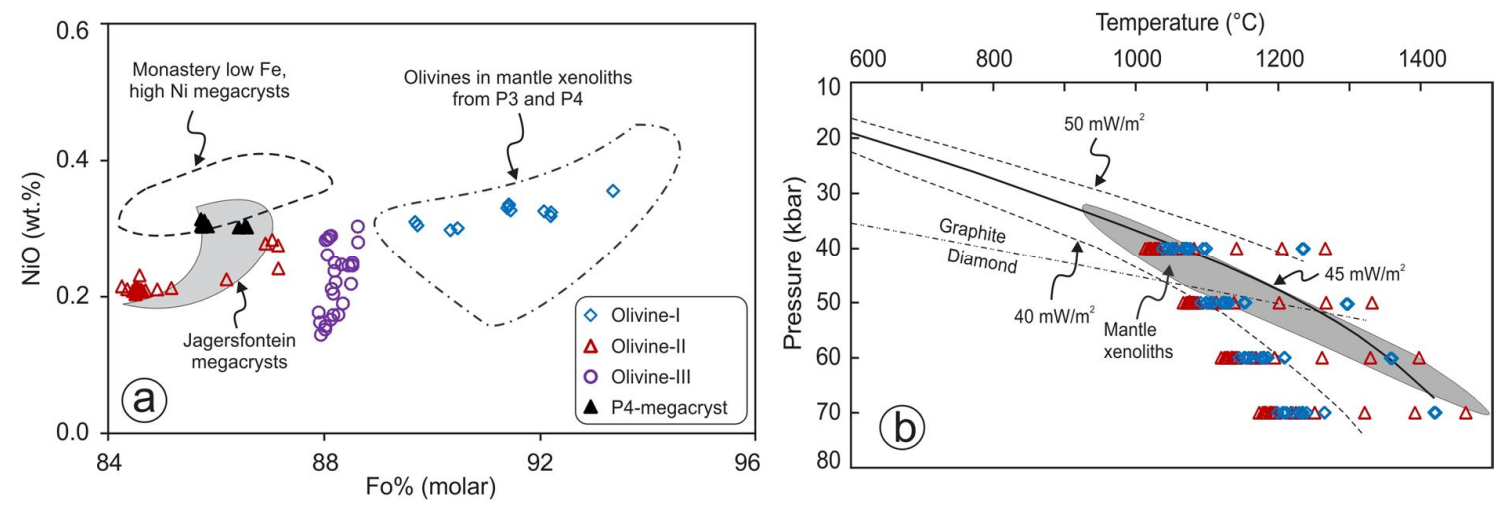

Figure 1: (a) Fo vs NiO plot of P3 olivines. Field of olivine megacrysts from Monastery and Jagerafontein kimberlites from Gurney et al. (1979) and Hops et al. (1992) respectively; (b) P-T plot showing intersection of the calculated temperatures for olivine I and II cores with xenolith geotherm beneath the WKF (thick line) and stability field of mantle xenoliths from the WKF. Data of mantle xenoliths in (a) and (b) from Nehru and Reddy (1989).

Olivine III rim, with oscillatory zoning in $\mathrm{Ca}, \mathrm{Cr}$, and $\mathrm{Ni}$, is of magmatic origin; the oscillatory zoning may be produced by rapid growth of crystal faces relative to slow diffusion of ions through the melt. Although it is widely believed that olivine crystallisation is linked to orthopyroxene assimilation in the melt, the relative timing of the two processes and the depth at which they occur are debatable. Based on the recent work of Stone and Luth (2017) it is possible that olivine crystallisation 
occurred concommitantly with orthopyroxene dissolution at depths shallower than $3.5 \mathrm{GPa}$ during kimberlite ascent.

Origin of phlogopites

Phlogopite I macrocrysts and nodules show evidences of deformation and locally contain vermicular shaped inclusions of $\mathrm{Cr}$-rich spinel. Their high $\mathrm{Cr}$-low Ti composition is similar to that of phlogopite cores from a variety of metasomatised mantle xenoliths and megacryst suites reported from South African kimberlites, and therefore, these phlogopites are considered to be xenocrysts. Phlogopite II grains occasionally contain inclusions of groundmass minerals indicating their magmatic origin, while their high $\mathrm{Cr}$-high $\mathrm{Ti}$ composition and deformed nature suggest crystallization at mantle depths. However, it is uncertain whether phlogopite II crystallized from the same magma from which phlogopite III crystallized or from a separate early magma pulse. The enrichment of $\mathrm{Cr}$ and $\mathrm{Ti}$ in phlogopite II and also in olivine III can be attributed to the crystallization of these phases from kimberlite magma prior to spinel crystallization.

\section{Conclusions}

Fe-rich macrocrystic olivine cores in P3 kimberlite are not related to a proto-kimberlite melt, but are derived from a megacryst suite produced by a distinct metasomatic event in the mantle. This contrasts with the suggestion of several workers on southern African and Russian kimberlites that Fe-rich olivines are cognate phenocrysts related to an early stage of kimberlite magmatism. The crystallisation of oscillatory-zoned olivine rim is interpreted to have occurred during kimberlite ascent.

\section{References}

De Hoog JCM, Gall L, Cornell DH (2010) Trace-element geochemistry of mantle olivine and application to mantle petrogenesis and geothermobarometry. Chemical Geology 270:196-215. doi: 10.1016/j.chemgeo.2009.11.017

Gurney JJ, Jakob WRO, Dawson JB (1979) The Mantle Sample: Inclusion in Kimberlites and Other Volcanics. American Geophysical Union, Washington, D. C., 227-243. doi: 10.1029/SP016p0227

Hops JJ, Gurney JJ, Harte B (1992) The Jagersfontein Cr-poor megacryst suite: towards a model for megacryst petrogenesis. Journal of Volcanology and Geothermal Research 50, 143-160.

Nehru CE, Reddy AK (1989) Ultramafic xenoliths from Wajrakarur kimberlites, India. In: J. Ross, et al. (Eds.), Kimberlites and Related Rocks, Proceedings of the Fourth International Kimberlite Conference, Vol. 2. Geol. Soc. Australia Spl. Pub. 745-759.

Shaikh AM, Patel SC, Ravi S, Behra D, Pruseth KL (2016) Mineralogy of the TK1 and TK4 "kimberlites" in the Timmasamudram cluster, Wajrakarur Kimberlite Field, India: Implications for lamproite magmatism in a field of kimberlites and ultramafic lamprophyres. Chemical Geology. doi: 10.1016/j.chemgeo.2016.10.030.

Stone RS, Luth RW (2016) Orthopyroxene survival in deep carbonatite melts: implications for kimberlites. Contributions to Mineralogy and Petrology 171, 1-9. doi:10.1007/s00410-016-1276-2 